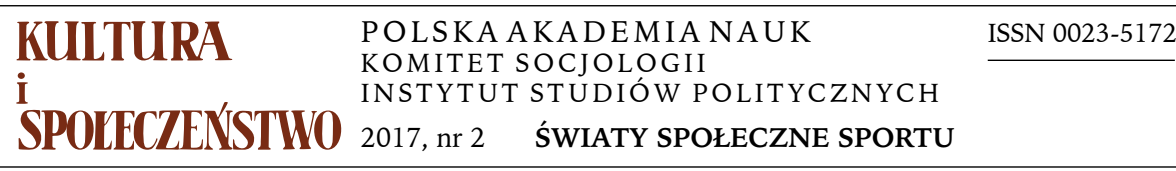

JACEK BURSKI

Uniwersytet Łódzki

\title{
PROCES STRUKTURYZACJI I INSTYTUCJONALIZACJI ŚWIATA SPOŁECZNEGO KIBICÓW PIŁKARSKICH I JEGO KONSEKWENCJE
}

Po 1989 roku w związku z przemianami społecznymi, ekonomicznymi i politycznymi, które zaszły w społeczeństwie polskim, możemy mówić o przyspieszeniu zmian zachodzących w świecie społecznym widowni futbolowej ${ }^{1}$. Jeden z kluczowych elementów tego procesu to dynamiczna strukturyzacja wspólnoty kibicowskiej, polegająca głównie na coraz wyraźniejszym zarysowywaniu się granic praktyk kulturowych kibicowania, a tym samym na przekształcaniu się mechanizmów wyłaniania się kolejnych subświatów. Przedstawione tezy są częścią przygotowywanej przez autora pracy doktorskiej na temat ruchu kibicowskiego $\mathrm{w}$ Polsce i znajdują oparcie $\mathrm{w}$ materiale empirycznym $\mathrm{w}$ postaci wywiadów przeprowadzonych w latach 2012-2013 z około trzydziestoma kibicami Łódzkiego Klubu Sportowego oraz danych pochodzących z obserwacji uczestniczącej, tekstów publikowanych przez fanów w formie książek i artykułów, a także na forach i stronach internetowych, wydawnictw okolicznościowych oraz innych wypowiedzi dotyczących świata piłki nożnej. Wyniki tych badań pozwalają między innymi odpowiedzieć na pytanie o historię i przebieg zmiany w świecie kibiców, opisać główne cechy tego procesu oraz konsekwencje, jakie niesie on dla aktorów społecznych zaangażowanych $\mathrm{w}$ ten świat.

Adres do korespondencji: jacekburski84@gmail.com

${ }^{1}$ W artykule sięgam do koncepcji światów społecznych Anselma Straussa (1990) i Tamotsu Shibutaniego (1955). Nie wyjaśniam tu założeń teorii, korzystam jedynie z podstawowych pojęć (światy i subświaty społeczne, procesy zachodzące w światach społecznych). 


\section{SKĄD WZIĘLI SIĘ KIBICE?}

Druga połowa XIX wieku to nie tylko okres dynamicznych zmian w gospodarce, polityce czy stosunkach społecznych. W efekcie zróżnicowanych procesów rozwoju przemysłu i gwałtownej urbanizacji społeczeństw zachodniej Europy dynamicznie rosła liczba członków zurbanizowanej klasy robotniczej ludzi coraz wyraźniej oderwanych od kultury ludowej i, co za tym idzie, tradycyjnych form spędzania czasu niepoświęcanego pracy. Jednocześnie rosnące w siłę nowoczesne państwa narodowe zaczęły wdrażać powszechny system edukacji i kontroli zdrowia, co - na poziomie różnego rodzaju polityk społecznych - stworzyło pole dla nowo powstających dyscyplin sportowych. Gry i zabawy - wcześniej zakorzenione przede wszystkim w kulturze ludowej sukcesywnie zmieniały oblicze, stawały się elementem kultury miejskiej i zalążkiem dyscyplin sportowych znanych nam dzisiaj.

Jedną $z$ takich gier był futbol, wywodzący się z tradycji zabaw z piłką. Richard Giulianotti (1999) korzeni współczesnej piłki nożnej doszukuje się w tzw. folk football'u, czyli nieskodyfikowanej wersji gry, w której nie było jeszcze szczegółowego podziału na role, dotykanie rękoma piłki było dozwolone, a nie ograniczone tylko do roli bramkarza, widownia płynnie zmieniała się w zawodników, a system rozgrywek po prostu jeszcze nie istniał. Jednak w przednowoczesnej odmianie gry można już odnaleźć elementy, które wiele lat później będą stanowiły o obliczu współczesnej dyscypliny. Zwracam uwagę na dwie podstawowe cechy tradycyjnej formy gry: powszechność dostępu oraz przejawy przemocy fizycznej zarówno na boisku, jak i wokół niego. Na przełomie XIX i XX wieku piłka nożna stała się jedną z najważniejszych globalnych rozrywek społeczeństwa masowego, a w ciągu kolejnych dekad także - jednym $z$ największych przemysłów sportowych. Obecnie w futbol gra się na całym świecie - nawet jeśli w jakimś kraju nie jest to najbardziej popularna dyscyplina sportowa, to najpewniej tam też znajdziemy profesjonalną ligę, kluby i podążających za nimi kibiców. Co interesujące, w związku z powstaniem takich instytucji jak FIFA czy UEFA często rośnie znaczenie polityczne państw niebędących potęgami w sensie demograficznym, a także sportowym. Głosy z Afryki czy Oceanii przesądzają o wyborze gospodarzy mistrzostw świata czy prezesów światowych federacji. Jednak najważniejsze zmiany zaszły w sferze finansowej futbolu. Ścisłe relacje między rozgrywkami, mediami i sponsorami doprowadziły do powstania układu ekonomicznego, który „pompuje” w piłkę nożną coraz większe pieniądze.

Wracając do pytania o korzenie kibicowania, trzeba cofnąć się do historii dyscypliny. Ostateczna kodyfikacja reguł nastąpiła w 1863 roku w Wielkiej Brytanii. To tutaj w 1854 roku zorganizowano pierwszy klub piłkarski - Sheffield FC, a w 1872 powstała Football Association (FA) — protoplasta federacji piłkarskich w kolejnych krajach. W tym samym roku rozegrano pierwszy mecz międzypaństwowy między Anglią a Szkocją. W 1888 roku po raz pierwszy na 
łamach prasy donoszono o zamieszkach na stadionie (Dudała 2004). Giulianotti (1999) zauważa, że ówczesne zmiany w futbolu mają charakter weberowskich procesów racjonalizacji. Modernizacja tradycyjnej gry doprowadziła do powstania struktury, która pozwalała na efektywne funkcjonowanie futbolu w zmieniającej się rzeczywistości społecznej. System stworzony w Wielkiej Brytanii sukcesywnie rozprzestrzeniał się na inne kraje, które poddawały się rosnącej modzie na futbol.

Istotne znaczenie miały zmiany $\mathrm{w}$ sferze pracy i czasu wolnego. W latach 1870-1880 zostały podniesione płace robotników i wprowadzono sobotę wolną od pracy. Więcej czasu i pieniędzy spowodowało wzrost zainteresowania rozgrywkami piłkarskimi. Znacznie nasiliła się ich popularność przede wszystkim wśród napływających do miast robotników. W ciągu dziesięciu lat średnia frekwencja na meczu ligi angielskiej podniosła się ponad pięciokrotnie (do poziomu 23100 osób w sezonie 1913-1914). Była to bez wątpienia pochodna procesów zachodzących na poziomie makrospołecznym: postępującej rewolucji przemysłowej, urbanizacji i racjonalizacji.

Wraz ze zmianą środowiska życia pojawiały się problemy tożsamościowe, na które odpowiedzią była po części identyfikacja z klubem piłkarskim: „Szczególna siła, jaką daje ekscytacja nieodmiennie towarzysząca meczom piłkarskim, w powiązaniu tym, że drużyna piłkarska dobrze nadaje się do reprezentowania członków określonej społeczności, były przyczyną intensyfikacji zainteresowania grą" (Taylor 1992, s. 6). Dzięki piłce nożnej możliwe było zaspokojenie potrzeby zakorzenienia w nowym miejscu i budowania zrębów lokalnej tożsamości. Futbol okazał się swoistym elementem kultury miejskiej i robotniczej, pozwalającym na reprezentację nowo budowanego kolektywnego „my”. Stał się ramą dla wspólnoty tworzącej się w środowisku miejskim.

Początki modernizacji futbolu były skażone wirusem przemocy. Była to przemoc pojawiająca się $\mathrm{w}$ określonym kontekście, przede wszystkim bezpośrednio związana $z$ wydarzeniami na boisku, a jej ofiarą padali głównie sędziowie i gracze drużyn przeciwnych (Dunning, Murphy, Williams 1991). Jak wskazują dane pochodzące jeszcze z czasów wiktoriańskich, ten rodzaj przemocy był w Wielkiej Brytanii spadkiem po okresie folk football, w którym wpisywał się w tradycyjny porządek gry. Giulianotti twierdzi, że pojęcie football hooliganism odnosi się do przesiąkniętych przemocą regularnych grupowych rywalizacji między odrębnymi futbolowymi subkulturami, które po raz pierwszy pojawiły się w Glasgow w latach dwudziestych i trzydziestych XX wieku. Rywalizacja fanatycznych kibiców Celticu i Rangers (dwóch największych szkockich klubów) stała się częścią piłkarskiej mitologii - jako starcie tzw. Old Firms. W szerokiej perspektywie zauważa się spadek liczby zamieszek na meczach w okresie międzywojennym. Eric Dunning razem ze współpracownikami starał się wyjaśnić tę zmianę przez odniesienie do koncepcji figuratywnych Norberta Eliasa (1980), twierdząc, że następowała ona za sprawą ówczesnego „cywilizowania się" mas, co polegało między innymi na wzroście poziomu nietolerancji dla 
przemocy fizycznej w sferze publicznej i inkorporacji do dominującego systemu wartości i norm (Dunning, Murphy, Williams 1988).

Początkowo kluczowe dla rozwoju piłki nożnej były zatem procesy zachodzące w sferze postępującej industrializacji i powstającej kultury masowej, po drugiej wojnie światowej zaś następuje czas ukonstytuowania się futbolu jako jednego z najważniejszych pól kultury sportu, będącej istotną częścią kultury popularnej. Gwiazdy futbolu stają się wówczas równie rozpoznawalne jak gwiazdy muzyki czy filmu². Co więcej, postępująca instytucjonalizacja piłki nożnej, jej coraz wyraźniejsze upolitycznienie, a także — być może najbardziej istotny czynnik - mediatyzacja, czyli pogłębianie związków z rozwijającymi się masowymi mediami, przede wszystkim telewizją, wsparły coraz szybszą komodyfikację tej dziedziny sportu. $Z$ tej perspektywy publiczność piłkarska stanowi pole ścierania się dwóch podstawowych tendencji: modernistycznej, którą należy rozumieć jako wzrost urynkowienia, znajdujący wyraz w przekształceniach struktury widowni futbolowej, idących w stronę uczynienia z piłki nożnej rozrywki klasy średniej, oraz tendencji antymodernistycznej, przejawiającej się w tradycyjnej kulturze kibicowania, której charakterystycznymi cechami są między innymi antysystemowość, skłonność do stosowania przemocy fizycznej na stadionie i poza nim, sprzeciw wobec postępującego urynkowienia futbolu kryjący się pod hasłem: Against modern football.

Lata dziewięćdziesiąte XX wieku są okresem zmian instytucjonalnych, przekładających się na globalny stan piłki nożnej. Chciałbym zwrócić uwagę na dwa przełomowe momenty: utworzenie Premier League w 1992 roku, będące symbolicznym końcem problemów z chuliganami na Wyspach Brytyjskich ${ }^{3}$, oraz powstanie Ligi Mistrzów, której działalność w ciągu blisko 25 lat (Puchar Mistrzów został przekształcony w nowe ciało w 1992 roku) przyspieszyła proces podziału świata społecznego kibiców (zob. m.in. Antonowicz, Kossakowski, Szlendak 2015), polegający na wykształceniu się dwóch podstawowych postaw: akceptacji bądź odrzucenia zmian związanych z coraz silniejszą ekonomizacją świata futbolu.

Historia rozwoju widowni piłkarskiej pokazuje, jak z masowych widowni lokalnych i efemerycznych (spotkaniowych) wspólnot skupiających się w meczowym „tu i teraz” wykształciła się społeczna struktura wykraczająca dalece poza pierwotne ramy. Potencjał tożsamościowotwórczy futbolu objawił się ze zdwojoną siłą w XX wieku, zwłaszcza w drugiej połowie. Piłka nożna weszła $\mathrm{w}$ przestrzenie społeczne potrzebujące nowych sposobów na budowanie wspólnotowych tożsamości. Choć nie działo się to ani płynnie, ani równomier-

\footnotetext{
2 Najbardziej wyrazistym przykładem jest północnoirlandzki piłkarz George Best, który był nazywany „piątym Beatlesem” (Best, Collins 2015).

${ }^{3}$ Starcia chuligańskie zdarzają się na Wyspach Brytyjskich do dziś, na przykład 7 marca 2015 r. podczas spotkania zespołów Aston Villa i West Bromwich Albion jeszcze przed zakończeniem meczu doszło do masowego wtargnięcia kibiców na boisko.
} 
nie, z czasem dla członków określonych segmentów struktury społecznej (np. młodych mężczyzn z klasy robotniczej) stała się generatorem sensów i identyfikacji wspólnotowych. Ponadto, z różnych powodów, chociażby ze względu na stale obecny w futbolu dyskurs rywalizacji narodowej — nigdy ostatecznie nie nastąpiło odejście od jednej z tzw. wielkich narracji. Piłka bowiem jest ambiwalentna. Sprawnie obsługuje zarówno tożsamości z poziomu lokalnego — każdy kibic ma swój piłkarski Heimat w postaci klubu, któremu kibicuje, jak i z poziomu ponadlokalnego - fenomen reprezentacji piłkarskich i ich zdolności do jednoczenia pod narodowymi barwami od lat pozostaje w kręgu zainteresowań socjologów. Dzięki temu futbol jest użytecznym narzędziem promowania, a jednocześnie polem funkcjonowania zjawisk globalizacyjnych i glokalizacyjnych (Antonowicz, Kossakowski, Szlendak 2015; Giulianotti 2006; Giulianotti, Robertson 2004, 2007a, 2007b).

Innym istotnym aspektem współczesnej kultury kibicowskiej jest to, co ogólnie możemy określić jako fascynację przemocą $\mathrm{w}$ futbolu. Jeszcze $\mathrm{w}$ średniowieczu dochodziło do bójek przy okazji piłkarskich potyczek, a i początki profesjonalnych rozgrywek również nie były wolne od problemów z zachowaniem widowni. Konglomerat masowości, przemocy i fanatyzmu w drugiej połowie XX wieku przyniósł zmianę: wykształcenie się jednego z dominujących wzorców współczesnej roli kibica piłkarskiego — fanatyka, głęboko zaangażowanego, nierzadko płynnie przybierającego rolę chuligana, działającego w kibicowskim świecie po to, by nie tylko śledzić wynik sportowy, ale również przekraczać to, co jest związane z samą grą. Wspólnota kibiców piłkarskich danego klubu potrafi przetrwać bez sukcesów sportowych, a czasami w ogóle bez niego samego ${ }^{4}$. Taka cecha jest konsekwencją zmiany polegającej na autonomizacji i odejściu od sukcesu sportowego jako głównego kryterium funkcjonowania więzi w środowisku kibiców oraz między nimi a klubem.

\section{KIM SĄ KIBICE PIŁKARSCY?}

Przy przeszukiwaniu literatury naukowej i nienaukowej ${ }^{5}$ można się natknąć na różne typologie kibicowskich zachowań i powiązane z nimi definicje. Przed zaprezentowaniem własnej propozycji, będącej sumą wniosków pochodzących $z$ różnych źródeł, chciałbym zwrócić uwagę na pewne charakterystyczne cechy roli kibica, które pozwalają na postawienie pytania o czynniki wyróżniające subświaty w świecie społecznym piłkarskich fanów.

\footnotetext{
${ }^{4}$ Przypadki rozwiązania klubów piłkarskich, degradacji i ratowania tych klubów przez kibiców nie są rzadkie. W Polsce po 1989 roku dosyć regularnie dochodzi do tego, że kluby, najczęściej z powodów finansowych, przestają istnieć. Wystarczy przypomnieć Lechię Gdańsk, Hutnika Kraków, Łódzki Klub Sportowy.

${ }^{5}$ Kibice sami często podejmują rozważania, kto jest kibicem albo na jakich kibiców dzieli się społeczność fanów. Struktura wspólnoty przekłada się również na hierarchię.
} 
Po pierwsze, kluczowym aspektem kibicowania jest nie tyle sam fakt sympatyzowania z daną drużyną, klubem czy zawodnikiem, ale długość trwania i siła więzi, jaka wytwarza się między jednostką a obiektem jej emocji. Skrajność tej relacji dobrze oddają historie chuligańskich bójek, w których zdarzają się ofiary śmiertelne. W mniej radykalnych przypadkach potencjał w niej tkwiący można zobrazować kosztami ekonomicznymi i biograficznymi, jakie kibic zdolny jest ponieść na rzecz swojej drużyny. Wysiłek finansowy w przypadku regularnego chodzenia na mecze jest oczywiście mocno zróżnicowany i zależy przede wszystkim od pozycji klubu, któremu się kibicuje. Karnet na spotkania klubu ekstraklasowego może być kilkukrotnie droższy niż w niższych ligach. Nie da się jednak nie zauważyć, że regularne, wieloletnie uczęszczanie na spotkania klubu średniego poziomu w naszym kraju to spory wysiłek finansowy. Dodać można jeszcze zakupy gadżetów, koszt meczów wyjazdowych, abonamentu telewizyjnego, by móc oglądać swoją drużynę. Przy czym mowa tu jest tylko o kosztach podstawowych — prawdziwie zaangażowany kibic oddaje nie tylko pieniądze, ale przede wszystkim inwestuje swój czas. Jeżeli jest aktywnym członkiem społeczności, może również pracować wolontaryjnie na jej rzecz. Według relacji kibiców to, co rozpoczyna się od pierwszego pójścia na mecz (często $z$ ojcem bądź starszym bratem, kibicowanie jest nadal rozrywką mocno zmaskulinizowaną), ostatecznie prowadzi do internalizacji zasad i norm panujących we wspólnocie kibicowskiej.

Po drugie, tożsamość kibicowska kształtuje się w poprzek klasycznych ról społecznych, wynikających $z$ umiejscowienia jednostki w strukturze takich układów społecznych, jak rodzina, praca, wykształcenie. Innymi słowy, rola kibica czasami przesłania inne powiązania społeczne jednostki. Generuje to pytanie natury socjologicznej: w jakim stopniu rola kibica może stać się prymarną wobec innych społecznych punktów odniesienia wykorzystywanych przez jednostki do budowania ich tożsamości? Kibicowanie stanowi interesujące pole badań, między innymi nad strukturą społeczną (z jakich segmentów społeczeństwa rekrutują się kibice?), konfliktami o podłożu klasowym (czy klasa średnia wypiera współcześnie klasę robotniczą z trybun?) czy relacjami między poziomem makro- a mikrotożsamościowym (jak ma się do siebie kibicowanie różnym, często antagonistycznie nastawionym klubom i kibicowanie reprezentacji danego kraju, gdy zakładamy działanie mechanizmów unifikujących?).

Po trzecie, kibicowanie jest praktyką performatywną. Co to oznacza? Tożsamość kibica wymaga prezentacji — inaczej nie zostanie potwierdzona w ramach społecznego procesu definiowania przynależności do grupy. Dopiero działanie o charakterze przedstawieniowym pozwala jednostce na prezentację swojego społecznego Ja wobec innych aktorów społecznych. Świat społeczny kibiców piłkarskich pozwala swoim członkom na korzystanie z różnych sposobów „autoekspozycji”. W zależności od miejsca zajmowanego w strukturze społeczności fanowskiej oraz społecznie przyjętych i akceptowalnych w niej praktyk kulturowych jednostka może zaprezentować się jako kibic określonego typu. 
Po czwarte, więź kibica z klubem ma charakter quasi-religijny. Temat ten podjęli polscy badacze Dominik Antonowicz i Łukasz Wrzesiński (2009), którzy do analizy zjawiska kibicowania zastosowali koncepcję niewidzialnej religii Thomasa Luckmanna. W ich rozumieniu piłkarscy fani stają się wyznawcami skupionymi wokół świętości — klubu. Tworzone są rytuały, symbole, narzędzia służące podtrzymaniu kultu. Pozostawiam tutaj na boku rozważania dotyczące przekształceń religijnych czy sposobu typologizacji kibiców ze względu na kryterium miejsca zajmowanego w tak pojmowanej wspólnocie. Szczególną uwagę chciałbym zwrócić na to, co jest powiązane z procesami zmieniającymi kibicowanie: postrzeganie zjawiska sportu przez pryzmat religijny — jako jednej $z$ nowych dróg odradzania się sacrum w codzienności, ale też jako fenomenu wyraźnie dążącego do wykształcenia stabilnych układów społecznych. Proces ten może być rozumiany jako instytucjonalizacja świata społecznego kibiców piłkarskich.

\section{STRUKTURYZACJA I INSTYTUCJONALIZACJA ŚWIATA SPOŁECZNEGO KIBICÓW PIŁKARSKICH}

Strukturyzację pojmuję jako postępujący w czasie proces wyodrębniania się kolejnych podgrup $\mathrm{w}$ ramach głównej metakategorii kibica. Zakładam tym samym, że nie ma jednej, całościowej definicji kibicowania. Poszczególne sposoby realizowania roli kibica różnią się zarówno na poziomie aksjologicznym, jak i behawioralnym. Różnicująca jest zwłaszcza sfera zachowań w trakcie meczu piłkarskiego, choć interesujący mnie okres po 1989 roku charakteryzuje rozszerzenie kultury kibicowskiej na praktyki niezwiązane z uczestnictwem w widowisku sportowym.

Proces wychodzenia poza skończone pod względem czasu i przestrzeni uniwersum meczu piłkarskiego może być widziany jako mechanizm przechodzenia, mówiąc językiem Victora Turnera $(2005,2010)$, od communitas do struktury, gdy to, co płynne, efemeryczne, powoli przekształca się w złożoną i skomplikowaną sieć relacji pomiędzy różnymi subświatami: kibiców „spokojnych” (tzw. pikników), chuliganów, ultrasów. Procesy zachodzące we wspólnocie kibicowskiej mają powiązania $z$ tym, co dzieje się w ogóle w świecie piłki nożnej, w pewnym sensie to odzwierciedlają. Postępująca strukturyzacja i komplikacja subświatów futbolu przyspiesza $\mathrm{w}$ drugiej połowie XX wieku. Pojawienie się zorganizowanych grup kibicowskich jest jedną z egzemplifikacji tego procesu. Inne to chociażby rozwój myśli taktycznej w ramach gry, wiedzy i praktyk treningowych czy implementacja technologii. Na styku futbolu, masowych mediów, polityki i biznesu działającego w polu sportu rodzą się nowe praktyki kulturowe, które bezpośrednio i pośrednio wpływają na analizowaną społeczność.

Instytucjonalizacja polskiego środowiska kibicowskiego dotyczy przede wszystkim praktyk organizowania się i formalizowania, które nasilają się z po- 
czątkiem XXI wieku wraz z coraz silniejszą presją formalną wywieraną na środowiska kibicowskie (zmiany w prawodawstwie określające i ograniczające aktywność fanów, chociażby w zakresie wyjazdów na mecze swojej drużyny) i naciskami o charakterze nieformalnym (rosnąca presja medialna związana $z$ powtarzającymi się działaniami chuliganów). Jest to czas zawiązywania się stowarzyszeń kibicowskich — proces symbolicznie zwieńczony powstaniem Ogólnopolskiego Związku Stowarzyszeń Kibiców w 2007 roku (formalna rejestracja nastąpiła w 2010 roku).

Innymi słowy, proces instytucjonalizacji to przemiana płynnej, efemerycznej grupy, charakterystycznej dla lat dziewięćdziesiątych poprzedniego wieku w instytucję o charakterze formalnego stowarzyszenia, posiadającego osobowość prawną $\mathrm{i}$ będącego $\mathrm{w}$ pewnym sensie reprezentacją środowiska na zewnątrz jego granic. Proces instytucjonalizacji może przybierać również inne wymiary. Może na przykład polegać na przejściu poszczególnych jednostek w ramach subświatów społecznych z pozycji fanatyków do roli działaczy i organizatorów. Odnoszę się tu bezpośrednio do tych wywiadów swobodnych z kibicami, które zawierały relacje dotyczące wchodzenia w struktury klubowe bądź okołoklubowe. Zmiana pozycji z kibica na działacza miała istotny wpływ na postrzeganie wspólnoty kibicowskiej, własnej roli w jej ramach czy szerzej — świata kibiców, futbolu i sportu. Również analiza struktury władzy we wspólnocie kibiców piłkarskich ujawnia kolejne aspekty instytucjonalizacji. Władza ma tu charakter dwojaki: formalny i nieformalny. W środowisku fanów są niepełniący żadnych funkcji oficjalnych liderzy, do których między innymi zaliczają się prowadzący doping czy członkowie grup chuligańskich. W zebranych relacjach wątek wpływu tych jednostek na decyzje dotyczące całej wspólnoty kibicowskiej powtarza się i świadczy o dwoistości struktury władzy. Członkowie stowarzyszenia działający w danej grupie mogą też stanowić elitarną część struktury władzy. To, w jaki sposób jest ustalana hierarchia i relacja między jednym i drugim poziomem zarządzania, dużo mówi o świecie społecznym kibiców i jego wewnętrznych podziałach.

Idea stowarzyszania się ma jeszcze jeden charakterystyczny rys, który można uznać za źródło nadziei na skuteczne „ucywilizowanie” środowiska kibicowskiego. Przez odniesienie do propozycji Norberta Eliasa (1980) można postawić tezę o wpływie mechanizmu organizowania się na inkorporację wartości społeczeństwa obywatelskiego. Kibice piłkarscy, będący ważnym problemem społecznym w latach dziewięćdziesiątych i na początku XXI wieku, mieliby się zmienić za sprawą wejścia $\mathrm{w}$ świat organizacji pozarządowych. Potwierdzenie takiej hipotezy wymaga jednak dodania kilku założeń. Po pierwsze, należałoby założyć, że w przypadku polskich fanów możemy mówić o wyraźnym przypisaniu zjawiska do konkretnej warstwy społecznej. Badania w społeczeństwie angielskim (Dunning, Murphy, Williams 1988) już dawno empirycznie potwierdziły mocno ugruntowane przekonanie, że większość widzów piłkarskich ma tam rodowód robotniczy. W polskim przypadku wobec braku 
danych (jednym z niewielu artykułów opisujących strukturę społeczną polskich kibiców jest tekst Mateusza Grodeckiego na temat badań CBOS; 2016) możemy jedynie założyć, że w grupach najbardziej zaangażowanych kibiców rzadko mamy do czynienia z przedstawicielami warstw wyższych. Należałoby też założyć, że poprzez fakt formalizacji stowarzyszenia dochodzi do transferu norm i zasad, które następnie przekładają się na działania konkretnych jednostek. Problemem staje się kryterium oceny tego wpływu - czy mielibyśmy mówić o spadku liczby zdarzeń związanych z przekroczeniem granic prawa na stadionach piłkarskich, czy raczej o rosnącym zróżnicowaniu tematów podejmowanych przez stowarzyszenia kibców, jak aktywne działania na rzecz inicjatyw niezwiązanych z samą wspólnotą kibicowską bądź klubem piłkarskim.

Jednak nawet jeśli wskazane założenia są w mocy, to doświadczenie ostatnich lat pokazuje, że jedynie w jednostkowych przypadkach można znaleźć potwierdzenie słuszności hipotezy o pozytywnym wpływie stowarzyszeń na zjawisko kibicowania. Ostatecznie, wydaje się, że na skutek wpływu różnego rodzaju czynników (egzo- i endogennych wobec środowiska kibicowskiego) doszło do marginalizacji idei stowarzyszania się jako istotnego motoru zmian, a pozytywny wymiar tendencji do instytucjonalizacji rozmył się w ogólnym ruchu ku radykalizacji politycznej.

\section{TYPOLOGIE KIBICÓW}

Podejmując temat typologii kibicowskich zachowań warto zauważyć, że już przestrzeń stadionu ma potencjał dystynkcyjny i jest fizycznym przedstawieniem metafory struktury społecznej — stadion jest podzielony zgodnie z różnego rodzaju dystynkcjami (tożsamościowymi: na kibiców domowych i przyjezdnych, klasowymi: na strefy VIP i tańsze sektory, niekiedy politycznymi czy etnicznymi). Podziały te przejawiają się również w kulturowo akceptowalnych zachowaniach poszczególnych typów widowni. Na przykład kibice przyjezdni nie są podzieleni według rodzaju biletów czy zasad zajmowania miejsc na stadionie. $Z$ reguły stanowią jednolitą grupę, a w wielu przypadkach jest to zaznaczane przez podobny ubiór (taki sam wzór koszulek czy czapek). Na stadionie zajmują jeden sektor, specjalnie przeznaczony i przygotowany na ich przyjazd. To „skoszarowanie” jest przymusowe, nie wolno poruszać się poza wyznaczonym terenem. $Z$ reguły tej grupie kibiców towarzyszy zwiększona grupa służb ochrony. Należy dodać, że tzw. wyjazd jest swego rodzaju kolejnym szczeblem w rozwoju kariery kibicowskiej i większość mniej „gorących” fanów nie uczestniczy w tej formie kibicowania. Ich zachowanie stosunkowo często cechuje większa agresja niż w przypadku kibiców gospodarzy. Natomiast kibice „domowi” dzielą się nie tylko ze względu na zajmowane miejsca. Można zaobserwować podział ze względu na stopień zaangażowania $\mathrm{w}$ doping $\mathrm{w}$ trakcie spotkania, część kibiców włącza się sporadycznie. Zaangażowanie zależy od 
przebiegu spotkania, jego stawki, rywala itp. (np. mecze derbowe są spotkaniami, w których $z$ reguły $\mathrm{w}$ dopingu bierze udział cały stadion).

Powyższy pobieżny opis o charakterze etnograficznym należy uzupełnić szerszą relacją $z$ koncepcji naukowych, w których podejmuje się wątek typologii zachowań kibicowskich. Badacze społeczni zajmujący się tym tematem stosują różne kryteria podziału. W pracach Petera Marsha (1978a, 1978b) dyferencjacja kategorii kibiców opiera się głównie na ich funkcji w grupie kibicowskiej skupionej wokół danego klubu. Kluczowa propozycja Richarda Giulianottiego (2002) to podział ze względu na typ więzi, a kategoryzacja zaproponowana przez polskich socjologów (Antonowicz, Kossakowski, Szlendak 2015) polega na rozróżnieniu postaw wobec postępującej modernizacji świata futbolu. Problem różnicowania się świata społecznego kibiców był przez lata i jest nadal jednym z głównych pól debaty naukowej. Co więcej, żadna z propozycji nie zdominowała innych. Tym bardziej należy zacząć od dekonstrukcji podziału kibiców funkcjonującego przede wszystkim w języku potocznym i stosunkowo często wykorzystywanego w debacie publicznej nad zjawiskiem kibicowania.

Zaproponuję zatem opis stanu debaty przez odwołanie się do kluczowych pojęć funkcjonujących w „wewnętrznym” i „zewnętrznym” polu sporu o kibicowanie. Wewnętrzne pole obejmuje przede wszystkim to, co możemy uznać za głos samych kibiców (w tym różnego rodzaju publicystyka kibicowska, wypowiedzi na forach i w mediach społecznościowych, książki i filmy, a także przekaz, który niosą oprawy, flagi, banery, wlepki i inne przekaźniki treści kibicowskich). Na zewnątrz tak zakreślonej debaty kibicowskiej umieściłbym to, co jest produkowane przez różnego rodzaju ekspertów, władze, innych uczestników dyskursu publicznego, niekoniecznie blisko związanych ze światem futbolu. Tu znalazłaby się publicystyka prasowa oraz internetowa, wypowiedzi medialne czy komunikaty władz. Interesującą cechą wspólną obu pól jest pewna schematyczność.

Wydawać by się mogło, że za kryterium konstruowania różnych typów kibicowania $\mathrm{w}$ dyskursie o kibicach może zostać uznany stosunek do przemocy (innymi słowy skłonność albo brak skłonności do stosowania jej różnych form). Jednak bliższe przyjrzenie się dyskusjom wewnętrznym, przede wszystkim wśród samych kibiców piłkarskich, uwydatnia raczej wątek autentyczności i zaangażowania we wspólnotę jako kluczowe kryterium. Tym samym to nie skłonność do ataków na rywali z innych grup kibicowskich wyznacza linię podziału, ale raczej poziom kosztów, jakie jednostka jest w stanie ponieść realnie i potencjalnie, funkcjonując $w$ takiej wspólnocie. Zgodnie $z$ tym tokiem myślenia w debacie publicznej można wskazać dwa podstawowe typy kibiców.

Fan atyk, typ obejmujący dwa podtypy:

Chuligan - wywodzący się przede wszystkim z futbolowej kultury Wysp Brytyjskich, gdzie przemoc fizyczna odgrywała kluczową rolę w latach sześćdziesiątych-osiemdziesiątych poprzedniego wieku, a następnie — od przełomu lat osiemdziesiątych i dziewięćdziesiątych — była 
konsekwentnie ograniczana i wypychana ze stadionów na rzecz dominacji modelu konsumenckiego. Przykładem wpływu angielskiego wzoru kibicowania na inne kultury fanów w Europie jest opisana przez Ramona Spaaija (2006) inkorporacja zachowań chuligańskich w Holandii. Także w Polsce lat dziewięćdziesiątych hasło hooligans dobrze oddaje wpływ, jaki na rodzimą kulturę kibicowską miał fenomen angielskich kibiców.

Ultras - analiza systemów aksjonormatywnych pokazuje, że przemoc fizyczna jest ich cechą jak najbardziej obecną i istotną, ale cechą charakterystyczną jest przygotowywanie i prezentowanie tzw. opraw, czyli skomplikowanych synchronizacji elementów graficznych (flagi, kartoniady, banery) z pirotechniką i śpiewem. Widać tu wpływy zachowań widowni południowoamerykańskich, dla których tworzenie specjalnych choreografii jest nieodłączne od kibicowania. Ruch ultras na kontynencie europejskim pojawił się we Włoszech, teraz obejmuje prawie całą Europę, a najbardziej aktywny jest w Niemczech, Polsce i na Bałkanach. „Piknik” (albo „Janusz”) jest wszystkim tym, czym fanatyk nie jest. Kibic w piknikowym stylu nie dopinguje (albo robi to niewłaściwie), nie jeździ na mecze wyjazdowe swojej drużyny, nie bierze udziału w akcjach chuligańskich ani nie przygotowuje opraw. Piknik - jako konsument w globalnym markecie piłkarskim - wybiera to, co go interesuje, a nie podąża za jedną drużyną. Kibicuje lepszym, tym, którym w danym momencie się wiedzie. Podążanie za sukcesem sportowym jest zatem podstawowym mechanizmem przyciągającym kibica o mniej fanatycznym usposobieniu do jego (tymczasowo) klubu.

Interesujący jest charakter wzajemnej relacji tych dwóch sposobów opowieści o świecie kibicowskim w wewnętrznej i zewnętrznej sferze dyskursu o kibicach piłkarskich. Wewnętrzne pole debaty jako wzorzec zachowań wskazuje - co dla uważnego obserwatora polskiej sceny kibicowskiej nie jest zaskoczeniem - kibiców fanatycznych, a tzw. pikników traktuje z dystansem bądź wrogością - uczestnicy tego pola widzą w nich nieautentycznych konsumentów, których wieź z klubem ma charakter płytki, krótkotrwały i zależny od sukcesu sportowego, co dyskursywnie wyklucza z grona „prawdziwych” (czytaj: autentycznych) kibiców. Wewnętrzny dyskurs kibicowski ustanawia autentyczność i zaangażowanie jako główne kryteria oceny statusu jednostki w strukturze kibicowskiej i odnosząc je do rzeczywistości świata społecznego ustanawia podziały na lepszych i gorszych widzów. Przedstawiciel warstwy "Januszów” stoi najniżej w takiej społecznie skonstruowanej hierarchii.

W zewnętrznym dyskursie o piłkarskich widzach kierunek wartościowania zostaje odwrócony. Fanatycy odgrywają rolę tzw. folk devils, by użyć klasycznego pojęcia z pola badań nad paniką moralną (moral panic) (Cohen 2002; Critcher 2008). Ich pojawienie się $\mathrm{w}$ dyskursie medialnym prawie zawsze jest wiązane z zagrożeniem bezpieczeństwa i łamaniem prawa. Dobrym przykładem tego, jak dyskurs obudowuje rolę fanatycznego kibica określonymi cechami społecznymi, jest historia pojęcia „kibol”. Samo słowo, wywodzące się z gwary wiel- 
kopolskiej, nie ma nacechowania pejoratywnego. Jednak w ostatnich latach obrosło w zdecydowanie negatywne konotacje i stało się pojęciem zastępczym dla dominującego w latach dziewięćdziesiątych określenia „pseudokibic” czy „szalikowiec”. Sensy ich obydwu splotły się w „kibolu” — z jednej strony mamy element fanatyzmu (,,szalikowiec” to kibic dopingujący, odziany odpowiednio do swojej roli, wyróżniający się z tłumu) i zagrożenia („pseudokibic” to ktoś, kto łamie społeczną regułę kibicowania, wypacza ją). Niewątpliwie to, co działo się w debacie publicznej wokół tego słowa-symbolu, stanowi istotny wątek historii zmiany społecznej zachodzącej na polskich stadionach, której efektem końcowym jest radykalizacja i mobilizacja polityczna środowiska kibicowskiego.

Zamiast podsumowania chciałbym zakończyć pytaniem o przyszłość świata społecznego kibiców piłkarskich w Polsce. Biorąc pod uwagę jego najnowszą historię, obejmującą okres od 1989 roku do dziś, można dostrzec, że zmiana sceny kibicowskiej kształtuje się inaczej niż oczekiwano jeszcze w czasach Euro 2012 (Burski 2013). Przede wszystkim należy podkreślić, że załamuje się proces „uczenia się” przez środowiska kibicowskie funkcjonowania w ramach społeczeństwa obywatelskiego, czemu miała sprzyjać instytucjonalizacja. Stowarzyszenia kibiców nadal istnieją i wpisały się na stałe w „krajobraz” stadionów, ale ich znaczenie maleje. Wygasł bowiem powód, dla którego stały się one ważnym graczem w polu debaty publicznej na temat kibicowania. Tym powodem było nadchodzące Euro 2012 i rozpętana w maju 2011 roku po zajściach podczas finału Pucharu Polski (mecz między Lechem Poznań i Legią Warszawa) nagonka medialna i polityczna. Ogólnopolski Związek Stowarzyszeń Kibiców zwiększył wówczas swoje znaczenie przede wszystkim w ramach wewnętrznego dyskursu kibicowskiego. Przedstawiciele kibiców brali również udział w przygotowaniu zmian Ustawy o bezpieczeństwie imprez masowych ${ }^{6}$.

Okazało się, że nieoczekiwaną konsekwencją bardziej zdecydowanego zaangażowania $\mathrm{w}$ debaty polityczne była (i nadal jest) radykalizacja środowisk kibicowskich. Nie ma tu miejsca na szersze potraktowanie tego wątku, ale należy zaznaczyć, że kibice stanowią istotną siłę polityczną zarówno na poziomie krajowym, jak i lokalnym. Stają się więc atrakcyjnym partnerem dla wszelkich ruchów politycznych mających dostęp do liderów i mas kibicowskich. Dodatkowym czynnikiem jest „prawicowe wychylenie” obserwowane na polskich trybunach od lat dziewięćdziesiątych. Kapitał społeczny ulokowany we wspólnocie kibicowskiej przekłada się na kapitał natury politycznej ${ }^{7}$.

\footnotetext{
${ }^{6}$ Ostatnia nowelizacja tej ustawy weszła w życie w 2015 roku, ale towarzyszyła temu już dużo mniejsza presja medialna (Dróżdż 2014).

7 Oto przykład: w Łodzi obydwa środowiska kibicowskie wprowadziły swoich przedstawicieli do Rady Miasta w wyborach do samorządu w roku 2014. Co ciekawe, ani jeden, ani drugi nie
} 
Zahamowanie albo ograniczenie wpływu stowarzyszania się na „cywilizowanie" kibicowskich mas nie oznacza jednak zastopowania procesu instytucjonalizacji. Pojawiają się nowe rodzaje formalizowania się wspólnoty kibicowskiej (np. ruch socios w Zabrzu i Olsztynie). Co więcej, traktując szerzej socjologiczną definicję instytucji, możemy uznać, że po okresie, w którym świat kibiców (podobnie jak całe społeczeństwo polskie) przeżywał różnego rodzaju perturbacje, obecnie możemy mówić o zastyganiu podziałów i dystynkcji powstałych albo przybierających wówczas na sile.

\section{BIBLIOGRAFIA}

Antonowicz Dominik, Wrzesiński Łukasz, 2009, Kibice jako wspólnota niewidzialnej religii, „Studia Socjologiczne", nr 1.

Antonowicz Dominik, Kossakowski Radosław, Szlendak Tomasz, 2015, Aborygeni i konsumenci: o kibicowskiej wspólnocie, komercjalizacji futbolu i stadionowym apartheidzie, Wydawnictwo IFiS PAN, Warszawa.

Best George, Collins Roy, 2015, Najlepszy, tłum. Robert Filipowski, Wydawnictwo Sine Qua Non, Kraków.

Burski Jacek, 2013, Euro 2012 - The End and the Beginning for Polish Football Supporters, „Przegląd Socjologiczny", t. 62 (3), s. 51-70.

Cohen Stanley, 2002, Folk Devils and Moral Panics: The Creation of the Mods and Rockers, Routledge, London-New York.

Čolović Ivan, 2002, The Politics of Symbol in Serbia: Essays in Political Anthropology, tłum. Celia Hawkesworth, Hurst, London.

Critcher Chas, 2008, Moral Panic Analysis: Past, Present and Future, „Sociology Compass”, t. 2(4).

Dróżdż Mateusz, 2014, Uchwalenie ustawy o bezpieczeństwie imprez masowych — przykład aktu państwa prawa czy państwa w prawie, „Ius Novum”, nr specjalny, s. 158-166.

Dudała Jerzy, 2004, Fani-chuligani. Rzecz o polskich kibolach. Studium socjologiczne, Wydawnictwo Akademickie Żak, Warszawa.

Dunning Eric, Murphy Patrick, Williams John, 1988, The Roots of Football Hooliganism: An Historical and Sociological Study, Routledge \& Kegan Paul, New York-London.

Elias Norbert, 1980, Przemiany obyczajów w cywilizacji Zachodu, tłum. Tadeusz Zabłudowski, Jacek Banaszkiewicz, Państwowy Instytut Wydawniczy, Warszawa.

Giulianotti Richard, 1999, Football: A Sociology of the Global Game, Polity Press-Blackwell Publishers, Cambridge UK-Oxford-Malden, MA.

Giulianotti Richard, 2002, Supporters, Followers, Fans, and Flaneurs: A Taxonomy of Spectator Identities in Football, ,Journal of Sport and Social Issues”, t. 26 (1), s. 25-46.

Giulianotti Richard, 2006, Glocalization, Globalization and Migration: The Case of Scottish Football Supporters in North America, „International Sociology”, t. 21 (2), s. 171-198.

Giulianotti Richard, Robertson Roland, 2004, The Globalization of Football: A Study in the Glocalization of the 'Serious Life', „The British Journal of Sociology”, t 55 (4), s. 545-568.

Giulianotti Richard, Robertson Roland, 2007a, Recovering the Social: Globalization, Football and Transnationalism, „Global Networks”, t. 7 (2), s. 166-186.

reprezentował partii prawicowej (jeden radny startował z listy Sojuszu Lewicy Demokratycznej, drugi z listy Platformy Obywatelskiej). 
Giulianotti Richard, Robertson Roland, 2007b, Sport and Globalization: Transnational Dimensions, „Global Networks”, t. 7 (2), s. 107-112.

Grodecki Mateusz, 2016, Liczni i fanatyczni. Skala kibicowania pitkarskiego w Polsce, w: A. Ostrowski (red.), Modern Football a świat kibiców 2. Interdyscyplinarne studia nad kultura futbolu, Wydawnictwo Naukowe Dolnośląskiej Szkoły Wyższej, Wrocław.

Marsh Peter, 1978a, Aggro: The Illusion of Violence, Dent, London.

Marsh Peter, 1978b, Life and Careers on the Soccer Terraces, w: Roger Ingham (red.), Football Hooliganism: The Wider Context, Inter-Action Imprint, London.

Spaaij Ramon F. J., 2006, Understanding Football Hooliganism: A Comparison of Six Western European Football Clubs, Vossiuspers UvA, Amsterdam.

Shibutani Tamotsu, 1955, Reference Groups as Perspectives, „American Journal of Sociology”, t. 60(6), s. $562-569$.

Strauss Anselm L., 1990 [1978], A Social World Perspective, w: Anselm L. Strauss (red.), Creating Sociological Awareness: Collective Images and Symbolic Representations, Transaction Press, New Brunswick, NJ.

Taylor Rogan P., 1992, Football and Its Fans: Supporters and Their Relations with the Game, 1885-1985, Leicester University Press, Leicester.

Turner Victor, 2005, Gry społeczne, pola i metafory: symboliczne działanie w społeczeństwie, tłum. Wojciech Usakiewicz, Wydawnictwo Uniwersytetu Jagiellońskiego, Kraków.

Turner Victor, 2010, Proces rytualny: struktura i antystruktura, tłum. Ewa Dżurak, Joanna Tokarska-Bakir, Państwowy Instytut Wydawniczy, Warszawa.

\section{THE STRUCTURIZATION AND INSTITUTIONALIZATION OF THE SOCIAL WORLD OF SOCCER FANS, AND THE CONSEQUENCES}

\section{Summary}

The author analyzes the segmentation and institutionalization of the social world of soccer fans in the context of global economic and cultural changes. He refers to the literature on the subject to present the genesis of this sport and the descriptions that have been made of its fans. In the empirical part, he views the fan phenomenon in Poland on the basis of press and internet materials, casual interviews with fans of the Łódź Sports Club, and fan behavior in stadiums (the 'framework'). Institutionalization and structurization in the social setting of Polish soccer fans are considered in connection with the economic and institutional changes after 1989 and global changes in the world of culture and the media. He proposes a typology of fans-the participants in the social world of soccer. He claims that the institutionalization of this world is underway but that organizing fans into associations is having a different impact on fan culture and the social world beyond than was earlier expected.

\section{Key words / słowa kluczowe}

football, soccer / futbol, soccer fans, football fans / kibice piłkarscy, sociology of sport / socjologia sportu, social worlds / światy społeczne 